\title{
Efforts to Improve Learning Motivation and Understanding in Early Children Through Serial Picture And Hand Puppet
}

\section{MG. Rini Kristiantari ${ }^{*}$}

${ }^{1}$ Pendidikan Guru Sekolah Dasar, Universits Pendidikan Ganesha, Singaraja, Indonesia

\section{ART I CLE I N F O}

Article history:

Received September 22, 2021

Revised September 24, 2021

Accepted October 30, 2021

Available online November 25, 2021

\section{Kata Kunci:}

Gambar Berseri, Boneka Tangan,

Motivasi, Pemahaman

Keywords:

Picture Series, Hand Puppet,

Motivation, Understanding

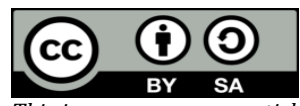

This is an open access article under the $\underline{C C}$ BY-SA license.

Copyright (C) 2021 by Author. Published by Universitas Pendidikan Ganesha.

\begin{abstract}
A B S T R A K
Proses pembelajaran yang terjadi saaat ini berjalan kurang maksimal. Pemberian rangsangan guna meningkatkan perkembangan anak dilakukan dengan cara yang sangat sederhana, umum, tanpa stimulasi media yang menarik. Siswa cenderung dibiarkan bermain sendiri di halaman sekolah. Hal ini mengakibatkan siswa merasa bosan dalam mengikuti pembelajaran. Tujuan penelitian ini yaitu mengembagkan boneka tangan dan gambar berseri sebagai media stimulasi bagi anak usia dini. Jenis penelitian ini yaitu pengembangan. Rancangan penelitian digunakan penelitian pengembangan ( $R \& D)$ rujukan Borg and Gall dengan tahapan yang telah dimodifikasi. Subjek uji produk terteliti yakni siswa taman kanak-kanak secara perorangan. Data penelitian dikumpulkan dengan metode kuisioner, selanjutnya data yang terkumpul dianalisis secara deskripstif kualitatif dengan mengacu pada teori Miles dan Huberman. Hasil uji ahli media terhadap lima komponen/indicator ternilai media gambar berseri 89.2\%, boneka tangan 97.2\%. Adapun hasil uji ahli materi terhadap lima komponen/indicator ternilai dari boneka tangan 100\% dan gambar berseri 100\%. Hasil uji ahli desain diperoleh 93\% untuk boneka tangan dan 80\% untuk gambar berseri. Dari persentase yang diperoleh tersebut menunjukkan bahwa kedua media layak digunakan sebagai media yang dapat merangsang tumbuh kembangnya kemampuan berbahasa anak usia dini. Implikasi penelitian ini yaitu media boneka tangan dan gambar berseri dapat diterapkan oleh guru dalam mengajar sebagai upaya meningkatkan motivasi dan hasil belajar anak usia dini.
\end{abstract}

\begin{abstract}
A B S T R A C T
The learning process that occurs at this time is not optimal. The provision of stimulation to improve children's development is carried out in a straightforward, general way, without enjoyable media stimulation. Students tend to be left to play alone in the schoolyard. It causes students to feel bored in following the lesson. This study aims to develop hand puppets and serial pictures as stimulation media for early childhood. This type of research is development. The research design used research development (R\&D) about Borg and Gall with modified stages. The product test subjects studied were kindergarten students individually. The research data was collected using a questionnaire method, then the data collected was analyzed descriptively qualitatively concerning the theory of Miles and Huberman. The results of the media expert test on the five components/indicators rated for serial image media $89.2 \%$, hand puppets $97.2 \%$. The results of the material expert test on five elements/valuable indicators of hand puppets are $100 \%$, and the picture series is $100 \%$. Design expert test results obtained $93 \%$ for hand puppets and $80 \%$ for serial images. The percentage received shows that both media are feasible to be used to stimulate the growth and development of early childhood language skills. This research implies that teachers can apply the media of hand puppets and serial pictures to increase motivation and learning outcomes of early childhood.
\end{abstract}

\section{INTRODUCTION}

Education is an essential asset for the progress of a nation. It causes every citizen to have and is obliged to follow it from early childhood education, primary education, secondary education to higher education, both formally and non-formally (Dagnew et al., 2020; Devi et al., 2020; Tajvidi et al., 2014). Early childhood education focuses on laying the foundation for children's growth and development (Alat \& Dedeoğlu, 2013; Kazu \& İș, 2018). In early childhood, aspects that must be developed are morals and religion, language and communication, socio-emotional (Charles et al., 2018; Herreras, 2017; Paul \& Singh, 2020). Early childhood education plays a role as a foundation for basic skills in preparing children to face further developmental tasks (Kazu \& İş, 2018; Kusumaningrum \& Wahyono, 2020; Poerwati \& Cahaya, 2018). The six aspects of development need to be stimulated appropriately so that children can grow and develop optimally. Therefore, educators in early childhood must be able to provide stimuli that can create all aspects of the child's development as a whole and maximally (Miller et al., 2021; Watini et al., 2020).

However, the current problem is that the learning process is not running optimally (Sutrisno et al., 
2021; Yates \& Twigg, 2017). Based on the observations made for three months to several kindergartens in the Denpasar City area, the results were relatively the same. The provision of stimulation to improve children's development is carried out in a straightforward, general way, without enjoyable media stimulation. Young children tend to be left to play alone in the schoolyard. Game stimulation that aims to improve language development is given without apparent readiness and goals so that they cannot achieve their target language (Dong et al., 2020; Josephidou, 2020; Vartiainen \& Kumpulainen, 2020). Based on this, it can be concluded that the stimulation of receptive and productive language development is rarely done using exciting media. Learning activities are carried out at this time only to fulfil curriculum targets in general, without paying attention to the feasibility and needs of children for their development. Learning that should be fun and make students learn comfortably and full of high enthusiasm is faced with mediocre learning, and children tend to feel bored (Dong et al., 2020; Wijayanti, 2019; Winther-Lindqvist, 2020).

These problems can be avoided if learning is packaged with the concept of edutainment (Ardianti et al., 2019; Pratiwi et al., 2018). The concept of edutainment refers to a learning process designed to combine education and entertainment content in harmony so that learning activities are fun (Pienimäki et al., 2021; Pratama et al., 2020). Adequate and attractive learning models and media prepared by teachers have an essential role in early childhood development (Chassiakos et al., 2016; Rahayuningsih, 2020). The use of monotonous learning methods without intense stimulation with attractive media facilities causes children to become bored in participating in learning in class or outside the classroom (Lan et al., 2010; Rekysika \& Haryanto, 2019; Zabrodina et al., 2015). Teachers must be able to choose models, methods or learning media that will be used in the learning process, of course, methods or learning media appropriate to the child's cognitive level (Gever et al., 2021; Tisza \& Markopoulos, 2021). One way to overcome these problems is by developing interesting and appropriate learning media for early childhood (Jolin \& Weller, 2011; Lau \& Lee, 2021). In addition to using the correct method, it is undoubtedly supported by exciting activities and media to develop children's language skills (Annisa et al., 2018; Dewi et al., 2019). Learning media is one of the tools that teachers can use to assist students in learning (Citra, 2017; Liyana \& Kurniawan, 2019; Rahayuningsih, 2020). This media can also increase students' motivation and enthusiasm for learning so that students are more motivated in learning (Alam \& Lestari, 2020; Febiharsa \& Djuniadi, 2018; Susiani et al., 2013). This media can be applied by teachers in learning so that students can understand learning easily. One form of media that is quite interesting for early childhood is serial images and hand puppets.

The learning media that will be developed are serial images and hand puppets. Series pictures are pictures that form a series of stories. Serial image media are several images that are interrelated and form a particular storyline (Ratihwulan \& Asmara, 2019; Trisnoningsih, 2021). Pictures are also interpreted as visual media that can be observed by everyone who sees them as a form of displacement from the actual situation, whether regarding scenery, objects, goods or life situations (Almutairi \& Shraid, 2021; Handayani et al., 2017; Lauc et al., 2020). Media series images are also called flow charts or stacked images. In addition to serial images, another medium is quite reliable as a medium that is useful as a medium for stimulating early childhood language development, namely hand puppets. Hand puppets are imitations of dolls generally in humans or animals (Chrisyarani, 2018; Triutami et al., 2014). This hand puppet has a size larger than the fingers of a human hand. It is because to move or operate hand puppets. Generally, teachers and early childhood will use their fingers to support the hands or doll heads (Dzulkarnain et al., 2016; Prananta et al., 2017). Hand puppets can be used as exciting learning media for children because dolls are universal toys (Khaliq et al., 2020; Mariana \& Zubaidah, 2015). Playing is not just an activity to fill children's playing time or for fun (Amri, 2018; Rahmatia et al., 2021). Children will be stimulated to train and develop brain work skills and hone children's imagination (Susiani et al., 2013). Apart from that, hand puppets are also very effective in helping children learn the language.

The findings of previous studies stated that hand puppets could increase students' enthusiasm for learning (Chrisyarani, 2018; Solihati, 2015). Other research findings also state that hand puppets can increase a pleasant learning atmosphere (Ayuswantana et al., 2020; Prananta et al., 2017). Other research findings also state that serial images can make it easier for students to learn to improve student learning outcomes (Hidayah et al., 2020; Suhandra, 2018). It can be concluded that teachers in learning can use hand puppets and picture series. There is no study on hand puppets and serial pictures as a medium of stimulation for early childhood. The advantages of hand puppets and serial images that will be developed areas storytelling media, which have many advantages and advantages. Children generally like dolls, so the stories told through the doll characters will attract their interest and attention. Children can also engage in doll play by playing with dolls. Even serial pictures can encourage the growth of a child's fantasy or imagination in developing their language skills. This study aims to develop hand puppets and serial pictures as stimulation media for early childhood. It is hoped that the developed media can help early childhood in learning. 


\section{METHOD}

This study uses a Research and Development (R\&D) design. This research intends to develop and produce a product, namely learning media in the form of serial images and hand puppets, to stimulate early childhood language development. The model used to develop the media is the Borg and Gall model. In carrying out this research, it was modified into five steps, namely collecting information/needs analysis, developing learning media in the form of serial images and hand puppets, conducting media construct validity tests and content/material tests, revising products based on expert and practitioner input, and reporting on the results of media product development. in the form of serial images and valid hand puppets (Yulando et al., 2019). The developed media will be assessed by experts, including 2 learning media experts, 1 learning design expert and 1 learning content expert. The product results from this study were then tested to get relevant and valid media results on media experts, teachers, school principals, and early childhood children in the Tunjung Group Kindergarten, Denpasar City (in some early childhood children as representatives). The methods used to collect data are observation, interviews, and questionnaires. The instrument used to collect data is a questionnaire. The grid of the questionnaire used is presented in Table 1 and table 2.

Table 1. Grid of Hand Puppet learning media experts

\begin{tabular}{|c|c|c|c|c|c|c|}
\hline \multirow[t]{2}{*}{ No } & \multirow[t]{2}{*}{ Rated Components/Indicators } & \multicolumn{5}{|c|}{$\begin{array}{c}\text { Frequency of subjects } \\
\text { who chose Alternative } \\
\text { Answer }\end{array}$} \\
\hline & & 5 & 4 & 3 & 2 & 1 \\
\hline 1 & Hand made puppets have an interesting design & & & & & \\
\hline 2 & $\begin{array}{l}\text { The characters in the hand puppet design are suitable for young } \\
\text { children }\end{array}$ & & & & & \\
\hline 3 & The materials used to make hand puppets are safe for children & & & & & \\
\hline 4 & $\begin{array}{l}\text { The size of the hand puppet is sufficient and suitable for early } \\
\text { childhood }\end{array}$ & & & & & \\
\hline 5 & $\begin{array}{l}\text { The choices and color combinations for each hand puppet character } \\
\text { are appropriate/good }\end{array}$ & & & & & \\
\hline
\end{tabular}

Table 2. Grid of Serial Picture Learning Media Experts

\begin{tabular}{|c|c|c|c|c|c|c|}
\hline \multirow[t]{2}{*}{ No } & \multirow[t]{2}{*}{ Rated Components/Indicators } & \multicolumn{5}{|c|}{$\begin{array}{c}\text { Frequency of subjects } \\
\text { who chose Alternative } \\
\text { Answer }\end{array}$} \\
\hline & & 5 & 4 & 3 & 2 & 1 \\
\hline 1 & The serial images created have an attractive design & & & & & \\
\hline 2 & The characters in the series design are suitable for early childhood & & & & & \\
\hline 3 & $\begin{array}{l}\text { The picture series shows the storyline that can stimulate the child to } \\
\text { speak }\end{array}$ & & & & & \\
\hline 4 & The size of the serial image that is made according to the space used & & & & & \\
\hline 5 & The color choices in the picture are clear & & & & & \\
\hline
\end{tabular}

Data analysis was carried out in a qualitative descriptive manner by presenting the results of the product feasibility test, which included testing the validity of content and construction and practicality. The percentage results obtained are used as a reference for the developed media to be used as media that can be used to stimulate language development in early childhood. The following is a Likert scale conversion table 3.

Table 3. Conversion of Five Scale Scores

\begin{tabular}{ccccc}
\hline \multirow{2}{*}{ No. } & \multirow{2}{*}{ Score Range } & \multicolumn{2}{c}{ Score } & \multirow{2}{*}{ Predicate } \\
\cline { 3 - 4 } & & By Numbers & With Letters & \\
\hline 1. & $90-100$ & 4 & $\mathrm{~A}$ & Very Worthy \\
2. & $80-89$ & 3 & $\mathrm{~B}$ & Worthy \\
3. & $65-79$ & 2 & $\mathrm{C}$ & Decent enough \\
4. & $54-64$ & 1 & $\mathrm{D}$ & less worthy \\
5. & $0-54$ & 0 & $\mathrm{E}$ & Not feasible \\
\hline
\end{tabular}




\section{RESULT AND DISCUSSION}

\section{Result}

Based on the results of data analysis on teacher responses and expert responses to several openly asked questions and statements related to the Learning Media products, picture series and hand puppets developed to stimulate early childhood language development can be described. The results of developing hand puppet media and serial images are presented in Figures 1. and 2.

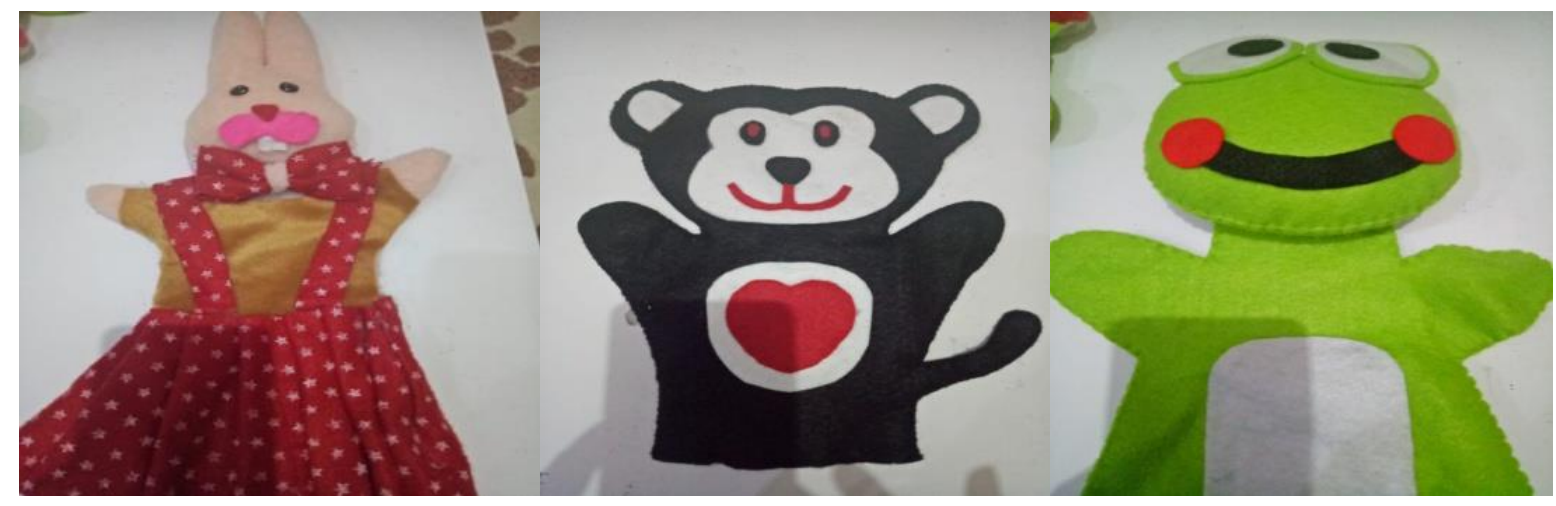

igure 1. Results of Hand Puppet Development

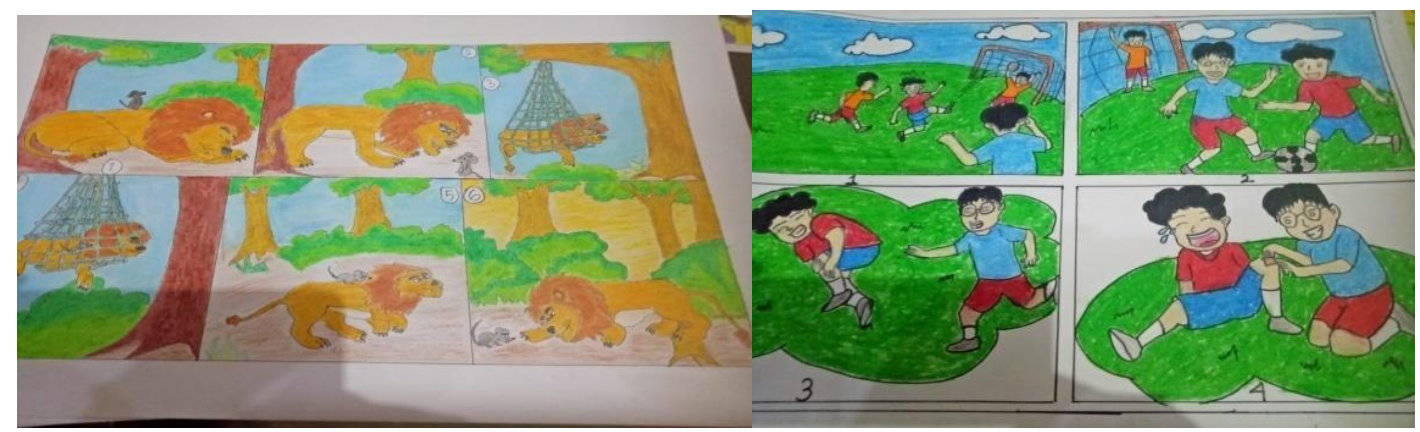

Figure 2. Results of Image Series Development

Theoretically and practically, the feasibility test results on the developed media constructs, Early Childhood Education practitioners argue that the serial picture media and hand puppets developed in this study are very feasible and can be used to teach and stimulate language development receptively productively in young children. The results of the data analysis are presented in Figure 3.

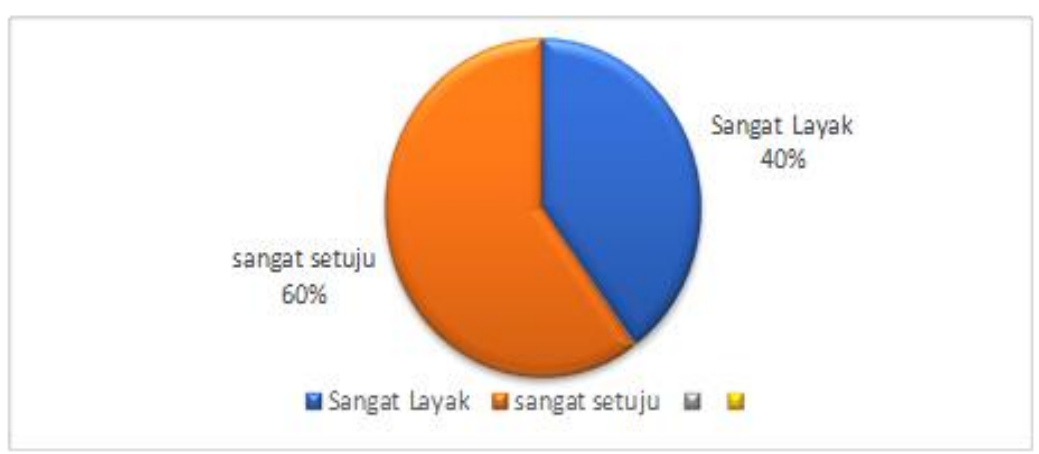

Figure 3. Results of Expert Assessment on Image Serial

From the feasibility test results of the three content experts, $40 \%$ stated that it was very feasible, and $60 \%$ stated that it was feasible that the serial image media developed could be used as a stimulation for early childhood language development. Likewise, the results of the analysis of hand puppet media. The results shown in the following chart show that the three content experts in the field of early childhood development stated that $100 \%$ strongly agreed that hand puppets were used as a medium for stimulating 
language development. In addition to strongly agreeing, $100 \%$ of them also stated that the hand puppets developed were suitable for use as a medium for stimulating early childhood language development.

Based on the results of data analysis, the assessment given by the learning content expert gets a value of $100 \%$, so that it gets excellent qualifications and is suitable for use. The results of the research provided by learning design experts got a score of $93 \%$ so that they got excellent qualifications and deserved to be used. The assessment given by the learning media expert got a score of $97 \%$ so that the qualification was excellent and suitable for use. It can be concluded that the hand puppet media developed is suitable for use in learning. Based on the results of data analysis, the assessment given by the learning content expert gets a value of $100 \%$, so that it gets excellent qualifications and is suitable for use. The research results provided by learning design experts get a score of $80 \%$ to get excellent qualifications and are suitable for use. The assessment given by the learning media expert got a score of $89.2 \%$ so that the qualification was excellent and feasible to use. It can be concluded that the serial image media developed is suitable for use in learning. After the developed media gets excellent qualifications, then product trials are carried out.

The results of data analysis carried out on the Hand Puppet media and serial images obtained the results of individual trials, getting a value of $100 \%$ so that the developed media received excellent qualifications and were suitable for use. The results of the data analysis carried out on the Hand Puppet media and serial images obtained the results of small group trials getting a value of $98 \%$ so that the developed media obtained excellent qualifications and were suitable for use. The results of individual and small group tests in early childhood show that children can freely and seem happy to express their imagination in the spoken words by playing with hand puppets while looking at serial pictures. In addition, children are also more concentrated and more enthusiastic about listening to the teacher's words when the teacher plays hand puppets. It can be concluded that the media developed is feasible to be applied in the learning process.

\section{Discussion}

Experts and students qualify the hand puppet media and serial pictures to be feasible to be applied in the learning process. Several factors, namely as follows, cause it. First, this media is feasible to be applied in learning because it impacts increasing student enthusiasm and motivation to learn. Media is an integral and inseparable part of children's lives, both electronic and concrete media (Hadders-algra, 2020; Lara \& Bokoch, 2021). It is because exciting learning media can make children not bored quickly (Gusmida \& Islami, 2017; Pienimäki et al., 2021). Media can also make children learn better, be more motivated, and understand things that are being studied faster (Fartina et al., 2019; Yusuf \& Widyaningsih, 2020). Based on the observations, it appears that the kindergarten teachers in the schools studied felt happy and motivated to carry out their learning activities better and innovate. The high enthusiasm and motivation of the teacher will influence the increased student morale. It influences a pleasant learning atmosphere (Aprinawati, 2017; Fitriani et al., 2019; Nurwahidah et al., 2021).

Second, the media developed in the form of hand puppets and serial pictures are appropriate for learning because it makes it easier for students to understand the material presented by the teacher. Students who use learning media will more easily understand the material presented by the teacher (Ngura et al., 2020; Puspita et al., 2016; Rahayuningsih, 2020). When playing hand puppets in front of his students, the teacher in his role as educator and teacher is no different from a Dalang playing his puppet in front of an audience. Hand puppets and puppets can be used as educative and influential media in learning to increase children's interest in learning. Likewise, with the image series. Serial images are exciting pictures, and students can understand the message. The method of delivery is easy and does not require expensive costs (Agung et al., 2017; Hidayah et al., 2020; Suhandra, 2018). Picture series serves as a creator of a suggestive atmosphere, a stimulus according to the child's development (Rizqi, 2018; Salfera, 2017). This media can be a bridge for students to imagine or create pictures and events or events based on the theme of the series of pictures shown. It causes students to understand the learning material delivered by the teacher more easily.

Third, the media developed in the form of hand puppets and serial pictures are appropriate to be applied in learning because they impact increasing student abilities. Picture series relate to each other so that it is a series of stories/events. Each picture is numbered according to the order of the story. This media is suitable for practising written expression skills or making up language development for early childhood (Mirnawati, 2017; Ratihwulan \& Asmara, 2019; Trisnoningsih, 2021).By observing the pictures laid out in the classroom, students and early childhood get certain concepts according to the theme being discussed (Alam \& Lestari, 2020; Febiharsa \& Djuniadi, 2018; Ogelman et al., 2018). Then in the following step, students are asked to pour it back into an essay in writing or tell stories orally. It provides stimulation to early childhood so that children's understanding and abilities increase. With the stimulation of playing hand puppets combined with serial images, children try to understand the story and the roles played. The more 
often children are invited to play, the better their language development is (Khoiruddin et al., 2016; Vartiainen \& Kumpulainen, 2020).

The findings of previous studies also stated that hand puppets could increase students' enthusiasm for learning (Ayuswantana et al., 2020; Prananta et al., 2017). The findings of previous research stated that hand puppets could improve the learning atmosphere that makes students feel happy (Chrisyarani, 2018; Solihati, 2015). The findings of previous studies also stated that serial pictures were effective in learning because they could improve student learning outcomes (Rizqi, 2018; Salfera, 2017; Suhandra, 2018). It can be concluded that serial image media and hand puppets are suitable for early childhood. The limitation of this study is that this research did not reach the media effectiveness test, but this media is feasible to apply because it has received excellent qualifications from experts. The advantages of the developed media, namely as a storytelling medium, have many advantages and advantages. Children generally like dolls, so the stories told through the puppet characters will attract their interest and attention. This research implies that teachers can apply the media of hand puppets and picture series to increase motivation and learning outcomes of early childhood. It is recommended for teachers to use learning media in teaching.

\section{CONCLUSION}

The results of the assessments given by experts regarding the media of hand puppets and serial images get excellent qualifications. Hand puppet media and serial pictures are appropriate to be applied in the learning process. The developed media can increase students' enthusiasm, motivation, understanding and increase student abilities.

\section{REFERENCES}

Agung, A. A. G., Widiana, I. W., \& Indrasuari, N. K. S. (2017). Pengembangan Aktivitas Pembelajaran Mengasosiasi Berbasis Media Gambar Berseri Dalam Meningkatkan Proses Kognitif Siswa. Jurnal Ilmiah Sekolah Dasar, 1(3), 138. https://doi.org/10.23887/jisd.v1i3.10323.

Alam, S. K., \& Lestari, R. H. (2020). Pengembangan Kemampuan Bahasa Reseptif Anak Usia Dini dalam Memperkenalkan Bahasa Inggris melalui Flash Card. Jurnal Obsesi : Jurnal Pendidikan Anak Usia Dini, 4(1), 284. https://doi.org/10.31004/obsesi.v4i1.301.

Alat, Z., \& Dedeoğlu, N. C.. (2013). Professional Development of Early Childhood Mentor Teachers in Teaching Math. Procedia - Social and Behavioral Sciences, 103(10). https://doi.org/10.1016/j.sbspro.2013.12.244.

Almutairi, T. S., \& Shraid, N. S. (2021). Teacher evaluation by different internal evaluators: Head of departments, teachers themselves, peers and students. International Journal of Evaluation and Research in Education, 10(2), 588-596. https://doi.org/10.11591/ijere.v10i2.20838.

Amri, N. A. (2018). Pengaruh Metode Bermain Peran Terhadap Kemampuan Komunikasi (Bahasa Ekspresif) Anak Taman Kanak-Kanak Raudhatul Athfal Alauddin Makassar. Jurnal Ilmu Pendidikan, Keguruan, Dan Pembelajaran, 1(2), 105. https://doi.org/10.26858/pembelajar.v1i2.4864.

Annisa, N., Saragih, A. H., \& Mursid. (2018). Pengembangan Media Pembelajaran Interaktif Pada Mata Pelajaran Bahasa Inggris. Jurnal Teknologi Informasi Dan Komunikasi Dalam Pendidikan, 5(2). https://doi.org/10.24114/jtikp.v5i2.12599.

Aprinawati, I. (2017). Penggunaan Media Gambar Seri Untuk Meningkatkan Kemampuan Berbicara Anak Usia Dini. Jurnal Obsesi: Jurnal Pendidikan Anak Usia Dini, 1(1). https://doi.org/10.31004/obsesi.v1i1.33.

Ardianti, S. D., Wanabuliandari, S., Saptono, S., \& Alimah, S. (2019). A needs assessment of edutainment module with ethnoscience approach oriented to the love of the country. Jurnal Pendidikan IPA Indonesia, 8(2), 153-161. https://doi.org/10.15294/jpii.v8i2.13285.

Ayuswantana, A. C., Sachari, A., \& Irfansyah, I. (2020). Pengaruh Nilai Islam pada Visual Pakaian Dewa dan Resi Boneka Wayang Jekdong Jawa Timur. Andharupa: Jurnal Desain Komunikasi Visual \& Multimedia, 6(1). https://doi.org/10.33633/andharupa.v6i1.2852.

Charles, D., Waldman, M., \& Fink, G. (2018). Measuring early childhood development at a global scale: Evidence from the Caregiver-Reported Early Development Instruments. Early Childhood Research Quarterly, 45. https://doi.org/10.1016/j.ecresq.2018.05.002.

Chassiakos, Y. R., Radesky, J., Christakis, D., Moreno, M. A., Cross, C., Hill, D., Ameenuddin, N., Hutchinson, J., Boyd, R., Mendelson, R., Smith, J., \& Swanson, W. S. (2016). Children and adolescents and digital media. Pediatrics, 138(5). https://doi.org/10.1542/peds.2016-2593.

Chrisyarani, D. D. (2018). Pengembangan Media Boneka Tangan dengan Metode Bercerita untuk Siswa Kelas V SDN Sudimoro 2 Kabupaten Malang. Jurnal Bidang Pendidikan Dasar, 2(1). 
https://doi.org/10.21067/jbpd.v2i1.2199.

Citra, D. (2017). Penggunaan Media Audio Visual dalam Pembelajaran Anak Usia Dini. Jurnal Cakrawala Dini, 5(2). https://doi.org/10.17509/cd.v5i2.10498.

Dagnew, A., Dar, B., Mekonnen, D., \& Dar, B. (2020). Innovative Research in Education eight students ' concept of photosynthesis , primary school : Ethiopia. International Journal of Innovative Research in Education, 7(1), 1-15. https://doi.org/10.18844/ijire.v7i1.4655.

Devi, M., Annamalai, M. A. R., \& Veeramuthu, S. P. (2020). Literature education and industrial revolution 4.0. Universal Journal of Educational Research, 8(3), 1027-1036. https://doi.org/10.13189/ujer.2020.080337.

Dewi, N. N. K., Kristiantari, M. . R., \& Ganing, N. N. (2019). Pengaruh Model Pembelajaran Picture And Picture Berbantuan Media Visual Terhadap Keterampilan Menulis Bahasa Indonesia. Journal of Education Technology, 3(4). https://doi.org/10.23887/jet.v3i4.22364.

Dong, C., Cao, S., \& Li, H. (2020). Young Children's Online Learning during COVID-19 Pandemic: Chinese Parents' Beliefs and Attitudes. Child Youth Serv Rev, 118. https://doi.org/10.1016/j.childyouth.2020.105440.

Dzulkarnain, I., Sumpeno, S., \& Christyowidiasmoro. (2016). Pengenalan Isyarat Tangan Menggunakan Leap Motion Controller untuk Pertunjukan Boneka Tangan Virtual. Jurnal Teknik ITS, 5(2). https://doi.org/10.12962/j23373539.v5i2.16462.

Fartina, Hizbi, T., \& Syahidi, K. (2019). Development of Interactive Physics Learning Media Macromedia Flash 8 Based on Straight Motion Material. Journal of Physics: Conference Series, 1539(1). https://doi.org/10.1088/1742-6596/1539/1/012023.

Febiharsa, D., \& Djuniadi, D. (2018). Pengembangan Media Pembelajaran Interaktif 3 Dimensi untuk Pembelajaran Materi Pengenalan Lingkungan Pada Anak Usia Dini di Indonesia. Journal of Studies in Early Childhood Education (J-SECE), 1(1). https://doi.org/10.31331/sece.v1i1.590.

Fitriani, D., Fajriah, H., \& Rahmita, W. (2019). Media Belajar Big Book dalam Mengembangkan Kemampuan Berbahasa Reseptif Anak Usia Dini. Jurnal Obsesi: Jurnal Pendidikan Anak Usia Dini, 4(1). https://doi.org/10.31004/obsesi.v4i1.197.

Gever, V. C., Tunca, E. A., Boluwatife, A. A., Nwogbo, V. C., \& Chinweobo-Onuoha, B. N. (2021). Visual media and learning: Effect of interactive television instruction as an intervention strategy for improving the critical thinking skills and disposition of out-of-school nomadic children in Nigeria. Learning and Motivation, 76. https://doi.org/10.1016/j.lmot.2021.101767.

Gusmida, R., \& Islami, N. (2017). The Development of Learning Media for the Kinetic Theory of Gases Using the ADDIE Model with Augmented Reality. Journal of Educational Sciences, 1(1), 1. https://doi.org/10.31258/jes.1.1.p.1-10.

Hadders-algra, M. (2020). Interactive media use and early childhood Uso de mídia interativa e desenvolvimento infantil precoce. Jornal de Pediatria, 96(3), 273-275. https://doi.org/10.1016/j.jped.2019.05.001.

Handayani, N. M. D., Ganing, N. N., \& Suniasih, N. W. (2017). Model Pembelajaran Picture and Picture Berbantuan Media Audio-Visual Terhadap Pengetahuan IPA. Journal of Education Technology, 1(3), 176. https://doi.org/10.23887/jet.v1i3.12502.

Herreras, E. B. (2017). Risk low math performance PISA 2012: Impact of assistance to Early Childhood Education and other possible cognitive variables. Acta de Investigación Psicológica, 7(1). https://doi.org/10.1016/j.aipprr.2017.02.001.

Hidayah, N., Wahyuni, R., \& Hasnanto, A. T. (2020). Pengembangan Media Pembelajaran Gambar Berseri Berbasis Pop-Up Book Untuk Meningkatkan Keterampilan Menulis Narasi Bahasa Indonesia. Jurnal Pendidikan Dan Pembelajaran Dasar, 7(1). https://doi.org/10.24042/terampil.v7i1.6182.

Jolin, E. M., \& Weller, R. A. (2011). Television viewing and its impact on childhood behaviors. Current Psychiatry Reports, 13, 122-128. https: //doi.org/10.1007/s11920-011-0175-5.

Josephidou, J. (2020). A gendered contribution to play? Perceptions of Early Childhood Education and Care (ECEC) practitioners in England on how their gender influences their approaches to play. Early Years. https://doi.org/10.1080/09575146.2019.1655713.

Kazu, İ. Y., \& İş, A. (2018). An Investigation About Actualization Levels of Learning Outcomes in Early Childhood Curriculum. Journal of Education and Training Studies, 6(3), 66. https://doi.org/10.11114/jets.v6i3.2928.

Khaliq, A., Barsihanor, B., \& Arifa, T. R. (2020). Pengaruh Penggunaan Media Boneka Tangan Terhadap Keterampilan Menyimak Siswa Kelas I Di Sdit Robbani Banjarbaru. Muallimuna Jurnal Madrasah Ibtidaiyah, 5(2). https://doi.org/10.31602/muallimuna.v5i2.2883.

Khoiruddin, M. A., Taulabi, I., \& Imron, A. (2016). Menumbuhkan Minat Baca Sejak Dini di Taman Baca Masyarakat. Journal An-Nafs: Kajian Penelitian Psikologi. https://doi.org/10.33367/psi.v1i2.295. 
Kusumaningrum, \& Wahyono. (2020). Developing A Pop-Up Storybook Based on Multicultural Education for Early Childhood Students. Jurnal Obsesi Jurnal Pendidikan Anak Usia Dini, 4(1). https://doi.org/10.31004/obsesi.v4i1.230.

Lan, K. L., Abdullah, M. C., \& Roslan, S. (2010). Understanding media violence and the development of aggressive behaviour of school children. Procedia - Social and Behavioral Sciences, 7(2), 522-527. https: //doi.org/10.1016/j.sbspro.2010.10.070.

Lara, R. S., \& Bokoch, R. (2021). Acta Psychologica Cognitive functioning and social media : Has technology $\begin{array}{llll}\text { changed us? Acta } & 103429 .\end{array}$ https://doi.org/10.1016/j.actpsy.2021.103429.

Lau, E. Y. H., \& Lee, K. (2021). Parents' Views on Young Children's Distance Learning and Screen Time During COVID-19 Class Suspension in Hong Kong. Early Education and Development, 32(6), 863-880. https: //doi.org/10.1080/10409289.2020.1843925.

Lauc, T., Jagodić, G. K., \& Bistrović, J. (2020). Effects of Multimedia Instructional Message on Motivation and Academic Performance of Elementary School Students in Croatia. International Journal of Instruction, 13(4), 491-508. https://doi.org/10.29333/iji.2020.13431a.

Liyana, A., \& Kurniawan, M. (2019). Speaking Pyramid sebagai Media Pembelajaran Kosa Kata Bahasa Inggris Anak Usia 5-6 Tahun. Jurnal Obsesi: Journal of Early Childhood Education, 3(1). https://doi.org/10.31004/obsesi.v3i1.178.

Mariana, S., \& Zubaidah, E. (2015). Pengaruh Penggunaan Media Boneka Tangan Terhadap Keterampilan Bercerita Siswa Kelas V Sd Se-Gugus 4 Kecamatan Bantul. Jurnal Prima Edukasia, 3(2).

Miller, P., Whitfield, K., Betancur, L., \& Votruba-Drzal, E. (2021). Income dynamics and behavior problems in early childhood, middle childhood, and the transition to adolescence. Journal of Applied Developmental Psychology, 77. https://doi.org/10.1016/j.appdev.2021.101345.

Mirnawati, M. (2017). Peningkatan Keterampilan Berbicara Siswa Kelas I SD melalui Media Gambar Seri Di SDN 06 Lubuk Alung Kabupaten Padang Pariaman. JPPI (Jurnal Penelitian Pendidikan Indonesia). https://doi.org/10.29210/02017120.

Ngura, E. T., Go, B., \& Rewo, J. M. (2020). Pengaruh Media Pembelajaran Buku Cerita Bergambar Terhadap Perkembangan Emosional Anak Usia Dini. Jurnal Ilmiah Pendidikan Citra Bakti, 7(2), 118-124. https://doi.org/10.38048/jipcb.v7i2.94

Nurwahidah, Maryati, S., Nurlaela, W., \& Cahyana. (2021). Permainan Tradisional Sebagai Sarana Mengembangkan Kemampuan Fisik Motorik Anak Usia Dini. PAUD Lectura: Jurnal Pendidikan Anak Usia Dini, 4(02), 49-61. https://doi.org/10.31849/paud-lectura.v4i02.6422.

Ogelman, H. G., Gungor, H., Korukcu, O., \& Sarkaya, H. E. (2018). Examination of the relationship between technology use of 5-6 year-old children and their social skills and social status. Early Child Development and Care, 188(2), 168-182. https://doi.org/10.1080/03004430.2016.1208190.

Paul, R., \& Singh, A. (2020). Does early childhood adversities affect physical, cognitive and language development in indian children? Evidence from a panel study. SSM - Population Health, 12(August), 100693. https://doi.org/10.1016/j.ssmph.2020.100693.

Pienimäki, M., Kinnula, M., \& Iivari, N. (2021). International Journal of Child-Computer Interaction Finding fun in non-formal technology education. International Journal of Child-Computer Interaction, 29, 100283. https://doi.org/10.1016/j.ijcci.2021.100283.

Poerwati, C. E., \& Cahaya, I. M. E. (2018). Project-Based Drawing Activities in Improving Social-Emotional Skills of Early Childhood. Jurnal Obsesi: Jurnal Pendidikan Anak Usia Dini, 2(2). https://doi.org/10.31004/obsesi.v2i2.114.

Prananta, Y. R., Setyosari, P., \& Santoso, A. (2017). Pengembangan Media Boneka Tangan Berbasis Digital Storytelling. Jurnal Pendidikan: Teori , Penelitian Dan Pengembangan, 2(5). https://doi.org/10.17977/jptpp.v2i5.9114.

Pratama, L. D., Lestari, W., \& Astutik, I. (2020). Efektifitas Penggunaan Media Edutainment Di Tengah Pandemi Covid-19. AKSIOMA: Jurnal Program Studi Pendidikan Matematika, 9(2), 413-423. https://doi.org/10.24127/ajpm.v9i2.2783.

Pratiwi, Ardianti, \& Kanzunnudin. (2018). Peningkatan Kemampuan Kerjasama Melalui Model Project Based Learning (Pjbl) Berbantuan Metode Edutainment Pada Mata Pelajaran Ilmu Pengetahuan Sosial. Refleksi Edukatika: Jurnal Ilmiah Kependidikan, 8(2). https://doi.org/https://doi.org/10.24176/re.v8i2.2357.

Puspita, P. M., Wirya, N., \& Antara, A. (2016). Penerapan Pendekatan Saintifik Berbantuan Media Kartu Gambar Untuk Meningkatkan Kemampuan Berbicara Di Tk Catur Paramita. Jurnal Pendidikan Anak Usia Dini Undiksha, 4(2). https://doi.org/10.23887/paud.v4i2.7809.

Rahayuningsih, S. (2020). Animation media of animal husbandry thematic science learning to stimulate scientific attitude in early childhood. International Journal of Scientific and Technology Research. 
https://doi.org/10.23887/jet.v3i1.17959 Article Metrics.

Rahmatia, R., Pajarianto, H., Kadir, A., Ulpi, W., \& Yusuf, M. (2021). Pengembangan Model Bermain Konstruktif dengan Media Balok untuk Meningkatkan Visual-Spasial Anak. Jurnal Obsesi : Jurnal Pendidikan Anak Usia Dini, 6(1). https://doi.org/10.31004/obsesi.v6i1.1185.

Ratihwulan, E., \& Asmara, R. (2019). Peningkatan Motivasi dan Prestasi Belajar Menulis Teks Eksposisi Menggunakan Model Discokaku Dipadu Gambar Berseri di SMA Negeri 5 Magelang. Transformasi: Jurnal Bahasa, Sastra Dan Pengajarannya, https://doi.org/10.31002/transformatika.v3i1.2006.

Rekysika, N. S., \& Haryanto, H. (2019). Media Pembelajaran Ular Tangga Bilangan Untuk Meningkatkan Kemampuan Kognitif Anak Usia 5-6 Tahun. Cakrawala Dini: Jurnal Pendidikan Anak Usia Dini, 10(1), 56-61. https://doi.org/10.17509/cd.v10i1.16000.

Rizqi, M. R. (2018). Peran Media Gambar Berseri Dalam Meningkatkan Motivasi Kemampuan Menulis Karangan Bahasa Arab. El-Ibtikar. EL-IBTIKAR: Jurnal Pendidikan Bahasa Arab, 7(2). https://doi.org/10.24235/ibtikar.v7i2.3363.

Salfera, N. (2017). Meningkatkan Kemampuan Menulis Teks Eksplanasi Dengan Menggunakan Media Gambar Berseri Pada Siswa Kelas VII. Jurnal EDUCATIO: Jurnal Pendidikan Indonesia, 3(2). https://doi.org/10.29210/12017295.

Solihati, S. (2015). Efektifitas Media Panggung Boneka untuk Meningkatkan Kemampuan Bercerita pada Anak Usia Dini. Modeling: Jurnal Program Studi PGMI, 2(2). https://doi.org/10.2345/modeling.v2i2.2176.

Suhandra, I. R. (2018). Pemanfaatan media gambar berseri untuk memperkaya kemampuan menulis naratif bahasa inggris siswa kelas IX MTS NW Nurul Wathon Pengembur Lombok Tengah. TRANSFORMASI: Jurnal Pengabdian Masyarakat, 14(1). https://doi.org/10.20414/transformasi.v14i1.576.

Susiani, P. E., Pudjawan, K., \& Renda, N. T. (2013). Penerapan Metode Role Playing Berbantuan Media Boneka Gambar Untuk Meningkatkan Kemampuan Bahasa Indonesia Anak Kelompok B TK Satya Kumara. Jurnal Pendidikan Anak Usia Dini Undiksha, 1(1). https: //doi.org/10.23887/paud.v1i1.1138.

Sutrisno, Zar'in, F., \& Salehcah, S. (2021). Local Content Curriculum Model for Early Childhood Scientific Learning. Jurnal Pendidikan Usia Dini, 15(1). https: //doi.org/10.21009/JPUD.151.05.

Tajvidi, M., Ghiyasvandian, S., \& Salsali, M. (2014). Probing concept of critical thinking in nursing education in Iran: A concept analysis. Asian Nursing Research, 8(2), 158-164. https://doi.org/10.1016/j.anr.2014.02.005.

Tisza, G., \& Markopoulos, P. (2021). International Journal of Child-Computer Interaction Understanding the role of fun in learning to code. International Journal of Child-Computer Interaction, 28, 100270. https://doi.org/10.1016/j.ijcci.2021.100270.

Trisnoningsih, D. (2021). Peningkatan Kemampuan Menulis Teks Eksplanasi Menggunakan Metode Quantum Learning Berbantuan Gambar Berseri. Jurnal Educatio Fkip Unma, 7(3). https://doi.org/10.31949/educatio.v7i3.1271.

Triutami, I. G. A. A. D., Sudhita, I. W. R., \& Tegeh, I. M. (2014). Penerapan Metode Bercerita Berbantuan Media Boneka Tangan Untuk Meningkatkan Perkembangan Bahasa Pada Anak. Jurnal Pendidikan Anak Usia Dini, 2(1). https://doi.org/10.23887/paud.v2i1.3239.

Vartiainen, J., \& Kumpulainen, K. (2020). Playing with science: manifestation of scientific play in early science inquiry. European Early Childhood Education Research Journal, 28(4). https: //doi.org/10.1080/1350293X.2020.1783924.

Watini, S., Aini, Q., Hardini, M., \& Rahardja, U. (2020). Improving Citizen's Awareness in Conserving Diversity of Malay Traditional Dances in Malaysia through the Art Appreciation Performed by Students of Early Childhood Education Study Program. International Journal of Psychosocial Rehabilitation, 24(8). https://doi.org/10.37200/IJPR/V24I8/PR280292.

Wijayanti, D. N. (2019). Effective learning of English through children's songs for madrasah ibtidaiyah (MI) students. Elementary, 4(1), 124-148. https://doi.org/10.21043/elementary.v4i1.1931.

Winther-Lindqvist, D. A. (2020). Caring well for children in ECEC from a wholeness approach - The role of moral imagination. Learning, Culture and Social Interaction, 1. https://doi.org/10.1016/j.lcsi.2020.100452.

Yates, E., \& Twigg, E. (2017). Developing creativity in early childhood studies students. Thinking Skills and Creativity, 23. https://doi.org/10.1016/j.tsc.2016.11.001.

Yulando, S., Sutopo, S., \& Franklin Chi, T. (2019). Electronic Module Design and Development: An Interactive Learning. American Journal of Educational Research, 7(10), 694-698. https: //doi.org/10.12691/education-7-10-4.

Yusuf, I., \& Widyaningsih, S. W. (2020). Implementing e-learning-based virtual laboratory media to students' 
metacognitive skills. International Journal of Emerging Technologies in Learning, 15(5), 63-74. https://doi.org/10.3991/ijet.v15i05.12029.

Zabrodina, I. K., Bogdanova, A. G., Bogdanova, V., Lilenko, I. Y., \& Richter, S. O. (2015). Experimental Learning of Foreign Language with the Socio-cultural Skills Development Method by Means of Modern Internet Technologies. Procedia - Social and Behavioral Sciences, 215(June), 141-146. https://doi.org/10.1016/j.sbspro.2015.11.602. 